\title{
Self-efficacy and Positive Youth Development: A Narrative Review of the Literature
}

\author{
Gisele de Rezende Franco*, 1 \\ Orcid.org/0000-0003-3000-6086 \\ Marisa Cosenza Rodrigues ${ }^{1}$ \\ Orcid.org/0000-0001-6711-3198
}

${ }^{1}$ Universidade Federal de Juiz de Fora, Juiz de Fora, MG, Brasil

\begin{abstract}
Positive Youth Development (PYD) addresses the promotion of the health of all adolescents, aiming to enhance their abilities and highlight the positive qualities of this period of development combined with resources from the environment and from significant people. Among these qualities, satisfactory self-efficacy beliefs are essential for achieving a healthy life, as they constitute resources that promote a positive adaptation to adult life. This narrative review aimed to discuss relationships between selfefficacy beliefs and developmental resources in different social domains. Articles were retrieved from the SciELO, PubMed, Web of Science, Scopus, CAPES and PsycINFO databases. The search terms 'self-efficacy' and 'positive youth development' were used, without delimiting the time interval. The scientific production was found to be recent, with 19 studies included that associated self-efficacy and PYD resources. These were predominantly cross-sectional studies, with samples mainly composed of high school students. Among the resources found, academic, physical, career and social support skills were highlighted. Individually, self-efficacy and academic performance presented more scientific productions, however, the association between these variables requires more research. Studies on selfefficacy and PYD are highlighted and some horizons for future research are pointed out.
\end{abstract}

Keywords: Self-efficacy, positive development, adolescents, scientific production.

\section{Autoeficácia e Desenvolvimento Positivo dos Jovens: Uma Revisão Narrativa da Literatura}

\section{Resumo}

O Desenvolvimento Positivo dos Jovens (PYD) aborda a promoção da saúde de todos os adolescentes, visando potencializar suas capacidades e ressaltar as qualidades positivas desse período evolutivo, combinadas com recursos do ambiente e de pessoas significativas. Dentre tais qualidades, crenças de autoeficácia satisfatórias são essenciais para a obtenção de uma vida saudável, pois configuram-se como recursos promotores de uma adaptação positiva à vida adulta. Objetivou-se na presente revisão narrativa

* Mailing address: Rua Doutor Moacir de Castro Xavier, 54, Bairro Linhares, Juiz de Fora, MG, Brazil 36060490. E-mail: gisele.franco2008@hotmail.com

Support: bolsista Coordenação de Aperfeiçoamento de Pessoal de Nível Superior (CAPES). 
discutir relações entre crenças de autoeficácia e recursos desenvolvimentais em diferentes domínios sociais. Foram recuperados artigos nas bases de dados SciELO, PubMed, Web of Science, Scopus, CAPES e PsycINFO. Empregaram-se os termos de busca autoeficácia e desenvolvimento positivo dos jovens, sem delimitar um intervalo temporal. A produção científica é recente, sendo selecionados 19 estudos que associam autoeficácia e recursos do PYD, com predominância de estudos transversais, e amostras compostas especialmente por jovens do ensino médio. Entre os recursos encontrados, destacam-se competências acadêmicas, físicas, de carreira e suporte social. Isoladamente, autoeficácia e desempenho acadêmico contam com produções científicas mais expressivas, mas a associação entre essas variáveis demanda mais pesquisas. Estudos sobre autoeficácia e PYD são destacados e alguns horizontes são apontados na direção de futuras pesquisas.

Palavras-chave: Autoeficácia, desenvolvimento positivo, adolescentes, produção científica.

\section{Autoeficacia y Desarrollo Positivo de los Jóvenes: Una Revisión Narrativa de la Literatura}

\section{Resumen}

El Desarrollo Positivo de los Jóvenes aborda la promoción de la salud de todos los adolescentes, buscando potenciar sus capacidades y cualidades positivas relacionadas con los recursos del ambiente y con las personas significativas. Dentro de estas cualidades, son necesarias las creencias de autoeficacia para lograr una vida saludable, además estas se constituyen en recursos promotores para adaptarse a la vida adulta. En la presente revisión se tuvo como objetivo discutir las relaciones entre autoeficacia y recursos del desarrollo en diferentes dominios sociales. Fueron recuperados artículos en las bases SciELO, PubMed, Web of Science, Scopus, CAPES y PsycINFO. Los términos empleados para la búsqueda fueron autoeficacia y desarrollo positivo de los jóvenes, sin delimitó un intervalo de tiempo. La producción científica es reciente, siendo seleccionados 19 estudios, con predominio de estudios transversales, y muestras compuestas por jóvenes del enseñanza medio. Entre los recursos encontrados se resaltan las competencias académicas, físicas, de carrera e apoyo social. De forma aislada, autoeficacia y desempeño académico cuentan con producciones científicas más expresivas, pero la asociación entre esas dos variables requiere más investigaciones. Estudios sobre autoeficacia y desarrollo positivo se destacan y horizontes se señalan en la dirección de futuras investigaciones.

Palabras clave: Autoeficacia, desarrollo positivo, adolescentes, producción científica.

Research related to self-efficacy in Positive Youth Development (PYD) contexts can support qualified professional practice in the field of prevention, by increasing positive qualities. Bandura (2004) defended the understanding of processes of personal change related to the adoption of favorable practices and the elimination of habits that are harmful to health. Accordingly, actions aimed at health promotion, defined as "the process of enabling people to increase control over, and to improve, their quality of life and health, including greater participation in the control of this process", are essential (World Health Organization [WHO],
1986). These actions establish a set of values, such as health and its social determinants, equity and social participation, marking diverse strategies directed toward the constitution of profitable public policies, such as the National Policy for Health Promotion. In Brazil, this policy includes, among its actions, the prevention and control of smoking, prevention of violence, reduction of morbidity and mortality due to alcohol/drug abuse, and reduction of traffic accidents (Ministério da Saúde, 2010).

Specifically, self-efficacy, according to Bandura (1977, p. 3), is defined as "the belief that the person has about his/her ability to 
organize and carry out courses of action required to achieve certain types of performance". Thus, the self-efficacy belief represents a mechanism that regulates human actions and directly impacts on the establishment of goals, the execution of tasks and the taking of decisions. Thus, people with high self-efficacy tend to establish more challenging aims, to better explore their environment, and to persist in the task in the face of obstacles, when compared to people with low self-efficacy (Pacico, Ferraz, \& Hutz, 2014; Sbicigo, Teixeira, Dias, \& Dell'Aglio, 2012).

The study of this construct is aligned with the social cognition model proposed through the social cognitive theory of Albert Bandura (2008), which sees human learning, motivation and performance as complex activities, affected by personal (knowledge, expectations, attitudes), behavioral (skills, practices) and socioenvironmental (social norms, peer influence) variables, which interact with each other. Cognitive social theory, like identity theory (Erikson, 1968/1976) and well-being theory (Seligman, 2011), to name a few, culminated in the adoption of more comprehensive models for understanding developmental phenomena. From this perspective, the Positive Youth Development (PYD) approach began in the 1990s in the United States, being defined as "engagement in prosocial behaviors and avoidance of behaviors that compromise and harm health and the future" (Lerner \& Galambos, 1998, p. 435).

As recommended by researchers in the field of PYD (Benson et al., 2006), it is imperative to study questions related to health, well-being and individual and environmental resources more deeply, aiming to generate healthier developmental trajectories. Based on this premise, PYD makes it possible to create programs that can prevent risky behaviors, as well as promote welcoming environments that support youth development activities (Senna \& Dessen, 2012). Damon (2004) highlighted that the PYD field encompasses the strengths, talents, and skills that young people can cultivate and ways to align them with resources and support from multiple social domains (family, school, peer group, community) to maximize the development of the individuals and society.

In order to achieve promising development, young people need to pass through experiences that prioritize their participation as protagonists or agents of their developmental process, in order to see the threats of the environment as opportunities and to choose effective strategies to deal with challenges. For this, the increase of self-efficacy is fundamental in the acquisition and maintenance of adaptive behavior patterns. Azzi and Polydoro (2006) argued that the predictive power of self-efficacy beliefs in relation to task choice, motivation or how one feels about certain activities evidenced the concept of perceived self-efficacy due to its explanatory power.

According to Bandura (1997), perceived self-efficacy, with the intention of fulfilling demands regarding the adoption of behaviors relevant to health and the accomplishment of tasks in different conditions, affects the levels of stress and anxiety of the young person, and, likewise, the environments (e.g., school) contribute to increasing the sense of youth efficacy. Thus, it can be verified that both the conditions of the environment and the actions employed to meet the demands - whether the physiological conditions of the young people or the beliefs of self-efficacy - interact and may allow (or not) the resolution of the stressor and/or anxiogenic condition.

It is important to emphasize that the inclusion of the positive development approach in the field of prevention has broadened the focus of research in the area and inserted the promotion of skills in interventions with positive ideas (Catalano et al., 2004; Franco \& Rodrigues, 2014; Seligman, 2011). The study of PYD in mapping the positive forces and values of young people and their social environment makes it possible to improve their educational and health outcomes (Benson, 2003). Thus, by increasing health promotion strategies based on the promotion of selfefficacy in this phase, it is possible to enhance these results, as well as to reduce the social vulnerability of young people.

In addition, there is empirical evidence showing that the increase in the skills assessed 
by programs focused on PYD accompanies a decrease in violent behaviors, school dropout, alcohol and drug use, high-risk sexual behavior, behavioral disorders, eating disorders, and depression (Benetti, Ramires, Schneider, Rodrigues, \& Tremarin, 2007; Catalano et al., 2004). In view of the high incidence of these problems, adolescent health has been a topic of growing interest not only among researchers but also in the agendas of the Pan American Health Organization (OPAS, 2007) and WHO (2013). In turn, Franco and Rodrigues (2014) and Senna and Dessen (2012) also highlight the prominence of innovative themes with studies on social skills and life skills, well-being, resilience, and risk and protection contexts, with theoretical and technical openness for proactive interventions emerging. Given this, it becomes relevant to invest in knowledge regarding PYD, which, according to studies promoted by Jacqueline Lerner et al. (2009), involves five resources, the "Five Cs", which are: Competence (positive vision of one's own actions in specific domains - cognitive, social, academic, physical, career, etc.); Confidence (sense of self-worth and selfefficacy - a notion that one can master a situation and produce positive results); Connection (positive links with people and institutions, reflecting two-way exchanges between the individual and the community, school, family and peers); Character (respect for social and cultural norms, morality and integrity) and, finally, Caring/ Compassion (feeling of empathy and sympathy for others).

From this perspective, Peter Benson (2003; Benson \& Scales, 2009; Benson et al., 2006), director of the Search Institute in Minneapolis, USA, indicated 40 developmental resources (20 external and 20 internal) that young people need to achieve positive results in their lives. According to the findings of the studies conducted, each of the 40 resources promotes the healthy development of adolescents and their environments. Among the 20 "external" resources, the following stand out: Support (family, neighborhood and school, offering a friendly and encouraging environment); Empowerment (adults value the young people, understanding them as active resources, and giving them useful roles in the community); Limits and expectations (definition of rules and clear consequences by the family, school and community, as well as the existence of a positive influence of the peers); Constructive use of time (engaging in creative activities and participating in programs organized for young people).

The 20 "internal" resources include: Commitment to learning (being motivated to succeed in school, and doing at least one hour of homework at home during school days); Positive values (helping other people, showing integrity and responsibility, and valuing equality); Social skills (knowing how to plan and make decisions, having interpersonal skills, such as empathy and friendship skills, and resisting pressure faced with risk situations); Positive identity (having a sense of control, purpose in life, optimism and high self-esteem). According to Santrock (2014), in studies conducted at the Search Institute, young people with more developmental resources engaged in less risky situations (such as alcohol and tobacco use). The author exemplified this question based on data from a survey of more than 12,000 high school students, indicating that $53 \%$ of the students with 0 to 10 resources reported having used alcohol three or more times in the previous month or drunk more than once in the previous two weeks, compared with only $16 \%$ of the students with 21 to 30 resources, or $4 \%$ of the students with 31 to 40 resources. It is thought that the greater the number of resources available, the greater the chances of preventing risky behaviors and promoting socially valued behaviors such as success in school and good health.

In view of the above, this article aims to present a narrative review of scientific publications focused on the relationship between selfefficacy and PYD, considering the multiple resources delimited by Benson (2003) and Lerner et al. (2009), as mentioned above. It should be noted that initiatives that explore this interface have emerged as specific proposals linked to investigations of risk factors, rather than the protection factors for youth development (Connor, George, Gullo, Kelly, \& Young, 2011; Hyde, 
Hankins, Deale, \& Marteau, 2008; Veselska, Geckova, Reijneveld, \& Dijk, 2011). Therefore, literature reviews are pertinent, since they aggregate the information obtained by several studies, highlight the similar and contradictory results and the gaps present in the literature and provide suggestions for future research, allowing a better understanding of the influence of self-efficacy beliefs on PYD.

\section{Method}

In order to achieve the objective of this study, a narrative review was carried out aiming for a synthesis of the current scientific literature. The narrative review technique was used to make it possible to bring together studies with different methods, obtaining the current state of knowledge available in a short period of time as the final product (Grant \& Booth, 2009; Rother, 2007). For the authors cited, this technique is adequate to describe and discuss the development of a given topic, from a theoretical/conceptual perspective, based on the interpretation and critical analysis of the literature, in order to favor the survey of questions and the acquisition and updating of the related knowledge.

Searches were conducted in the SciELO, PubMed, Web of Science, Scopus, CAPES and PsycINFO databases in August 2016. No timeframe was used for the inclusion of the publications, as the intention was to analyze the available production of self-efficacy beliefs involving the area of Positive Youth Development (analyzing the various resources included in it).

The process of collecting the material was carried out using the terms 'self-efficacy and positive youth development' in the English language, 'autoeficácia e desenvolvimento positivo dos jovens' in the Portuguese language, and 'autoeficacia y desarrollo positivo de los jóvenes' in the Spanish language. The field selected for searching was "subject" or "word" when the subject option did not exist. The results of each of the terms were cross-referenced using the Boolean operator "and" in order to restrict the search to documents that had both terms.
The criteria for the inclusion of the publications in this review were: studies in which the self-efficacy construct was the main axis. That is, studies containing this expression in the title or keywords, or with the abstract containing the explanation that the text was related to self-efficacy with positive aspects linked to PYD. In this stage 125 publications were found. Next, the documents that were not articles (theses, dissertations, editorials, books), articles repeated in the databases, and those with samples of children were eliminated, due to not being of the interest to this review. As a result, 12 articles were obtained, as described in Table 1.

Table 1

Description of the Bibliographic Search in the Databases Searched

\begin{tabular}{ccc}
\hline Database & Results & $\begin{array}{c}\text { Articles } \\
\text { selected }\end{array}$ \\
\hline SciELO & 3 & 1 \\
PubMed & 12 & 0 \\
Web of Science & 10 & 2 \\
SCOPUS & 21 & 2 \\
Capes & 54 & 6 \\
PsycINFO & 25 & 1 \\
\hline Total & 125 & 12 \\
\hline
\end{tabular}

In the second stage, the database was complemented with studies with the same approach, indicated in the bibliographic references of the studies that remained in the review, with seven new publications being added after analysis of concordance among the authors. In the end, this narrative review comprised a total of 19 articles that fulfilled the inclusion and exclusion criteria listed.

As highlighted by Grant and Booth (2009), in narrative review studies one may or may not use qualitative and quantitative techniques to analyze the scientific production identified, with this, it was decided not to use them in the treatment of the data in this review. The selected articles were read in their entirety, analyzed 
critically, and recorded in a protocol developed by the researchers, which contained an added summary of comments. The organization of the summary generated the following categories: author, year of publication, title, place of research, sample size, investigation domains (school, family, peer group, community) aim, study design (longitudinal, cross-sectional), measuring instruments to evaluate self-efficacy and intrinsic and/or extrinsic aspects of PYD, and, finally, the main results regarding the relationship between PYD resources and selfefficacy. Based on these categories, the main information obtained was grouped into three thematic axes by methodological or theoretical affinity, as detailed in the following section.

\section{Results and Discussion}

Table 2 presents the initial results of the studies selected. Among the nineteen studies targeted for this review, eight were conducted in the national context. Eleven studies were conducted in an international context, four of them exclusively in the USA and one concomitantly in the USA and Africa, one in Mexico, one in Italy, one in Spain, one in Malaysia, one in Colombia, and one in Israel. Regarding the time of the publications, a period of coverage corresponding to the years 1996 to 2016 was verified. The first work, indexed by the CAPES Portal, was published in 1996, however, from 2009 there was an increase in production, with 14 articles published since then.

In general, it was verified that studies associating self-efficacy with PYD resources are recent. In addition, international studies predominated, indicating the need for greater investigation of the issue in the Brazilian context. The main information obtained, based on the studies found, was inserted in the protocol mentioned containing the categories mentioned, grouped in the three thematic axes, namely: (a) Methodological characteristics; (b) Type(s) of evaluation of the self-efficacy and social domains; and (c) Implications of the association between self-efficacy and positive development resources.
Table 2

Number of Studies Identified $(N=19)$

$n$

\begin{tabular}{|c|c|}
\hline \multicolumn{2}{|l|}{ Origin } \\
\hline Brazil & 8 \\
\hline EUA & 4 \\
\hline EUA/África & 1 \\
\hline Mexico & 1 \\
\hline Itály & 1 \\
\hline Spain & 1 \\
\hline Maláysia & 1 \\
\hline Colombia & 1 \\
\hline Israel & 1 \\
\hline \multicolumn{2}{|l|}{ Year } \\
\hline 1996 & 1 \\
\hline 1999 & 1 \\
\hline 2005 & 1 \\
\hline 2006 & 1 \\
\hline 2008 & 1 \\
\hline 2009 & 2 \\
\hline 2011 & 3 \\
\hline 2012 & 1 \\
\hline 2013 & 1 \\
\hline 2014 & 2 \\
\hline 2015 & 3 \\
\hline 2016 & 2 \\
\hline
\end{tabular}

\section{Methodological Characteristics}

This thematic axis presents the information regarding the design of the studies and characteristics of the participants. Regarding the design, the majority were cross-sectional correlational studies, with only one adopting longitudinal methodology (Carvajal et al., 1999). It should be noted that the correlation studies allow the predictive factors of self-efficacy to be identified, however, they do not allow the verification of whether there is a causal relationship between the variables or the direction of this relationship. For example, in the case of the relationships 
found between self-efficacy and personal and social responsibility of the students (Sanmartín, Carbonell, \& Baños, 2011), it cannot be affirmed whether the personal and/or social responsibility of the young people caused a greater frequency of self-efficacy or, on the contrary, whether a high sense of self-efficacy made them more responsible in any area of life.

As shown in Table 3, the sample size varied from 35 (Noronha \& Ambiel, 2008) to 1,698 adolescents (Souza, Rech, Sarabia, Añez, \& Reis, 2013), with the mean age between 13 and 18 years. Regarding the participants, the majority of the studies had only adolescents as the target population, except the study by Noronha and Ambiel (2008), which included a sample of adolescents $(n=35)$ and also one of the parents of each participant $(n=35)$. In general, the studies were carried out with both boys and girls, while the only study involving adolescents and their parents as the target population did not collect the demographic data of the parents, only mentioning that there was a predominance of mothers $(67 \%)$.

\section{Type(s) of Evaluation of the Self-efficacy and Social Domains}

The studies varied regarding the type of self-efficacy belief investigated, considering the objectives proposed in each of them, as well as the variability of contexts in which this belief can be studied, for example, in the context of health and of education, or more generally. Studies were found in which the young people considered themselves capable when evaluating specific situations, as in the study by Carvajal et al. (1999) on the postponement of the beginning of sexual activity, or that of Leal et al. (2015) on career development. However, there are also studies focusing on the belief in the ability to perform various activities regardless of the situation presented (Johnson et al., 2012). These findings converge with the assumptions of Bandura (1977), emphasizing the fact that self-efficacy is related to a particular situation and, thus, directing researchers to construct evaluation measures for specific moments, presenting self-efficacy as a state. However, in contrast to what Bandura
$(1977,2006,2008)$ proposed in his studies, selfefficacy can also be generalized, since when oriented to one circumstance, it may affect beliefs in the capacity of the subject in another. In this sense, Pacico et al. (2014) defined general selfefficacy as a generalized and stable belief in the capacity to deal with challenges independent of the situation presented, being understood as a trait-like belief in one's own competence.

With regard to data collection instruments in general, the use of scales and questionnaires predominated, as shown in Table 3. To evaluate self-efficacy, 17 different instruments were adopted, with the most used being: measures containing subscales evaluating academic selfefficacy: Self-efficacy Scales (Perceived Competence Scale for Children-PCSC; Chung \& Elias, 1996), Escala de Autoeficácia Acadêmica (Guerreiro-Casanova et al., 2011), Cuestionario sobre la Autoeficacia Académica General (Gaxiola \& Armenta, 2016) and Self-efficacy Questionnaire for Children (Yap \& Baharudin, 2016). These were followed by, the Self-Efficacy Scale for Occupational Activities (EAAOc; Noronha \& Ambiel, 2008; Nunes \& Noronha, 2009, 2011); and the evaluation of self-efficacy for career development: Career Decision-making Self-efficacy Scale-Short Form (CDMSES-SF; Gushue, 2006), Career Decision Self-efficacy Scale-Short Form (CDSE; Di Fabio \& Kenny, 2015), and Inventário de Autoeficácia em Desenvolvimento da Carreira (CD-SEI; Leal et al., 2015).

Regarding the evaluation of the positive development resources, different instruments were used in each study, such as scales and questionnaires, and only one study (Johnson et al., 2012) used open questions or interviews with participants, aiming to evaluate the young people's perceptions of themselves (ethnicity), their community (intercultural attitudes) and daily lives. Among the main intrinsic resources investigated were: academic, social (e.g., empathy), physical, and career skills; commitment to learning; confidence (sense of self-worth, adoption of healthy lifestyles) and positive values (responsibility). The extrinsic resources verified included: social support (teachers, family members, peers and 
Table 3

Studies that Evaluated Self-Efficacy and its Relationship with PYD Resources

\begin{tabular}{|c|c|c|}
\hline Authors & $\begin{array}{l}\text { Sample }(n) \text {; social } \\
\text { domain }\end{array}$ & $\begin{array}{l}\text { Measuring instruments: } \\
\text { 1. Self-efficacy scale; 2. Measures of PYD resources }\end{array}$ \\
\hline $\begin{array}{l}\text { Braun-Lewensohn } \\
\quad(2015)\end{array}$ & $n=400 ;{ }^{\mathrm{d}}$ & $\begin{array}{l}\text { 1. Citizens' Efficacy; 2. Sense of Coherence Scale, Questionnaire of } \\
\text { Values, Youth Social Responsibility Scale, Hope Index }\end{array}$ \\
\hline Carvajal et al. (1999) & $n=827 ;{ }^{\text {a }}{ }^{\mathrm{c}}$ & $\begin{array}{l}\text { 1. Questionnaire of Self-efficacy about the Respondents' Confidence } \\
\text { in Refraining from Having Sex; } 2 \text {. Questionnaire of Delay the Onset } \\
\text { of Sexual Intercourse, Attitudes, Social Norms }\end{array}$ \\
\hline Chung \& Elias (1996) & $n=556 ;{ }^{\mathrm{a}}$ & $\begin{array}{l}\text { 1. Self-efficacy Scales: academic, social and physical; 2. National } \\
\text { Youth Survey of Antisocial and Delinquent Behavior, Life Events } \\
\text { Checklist, Social Competence Scales-Youth }\end{array}$ \\
\hline Contreras et al. (2005) & $n=120 ;{ }^{\mathrm{a}}$ & $\begin{array}{l}\text { 1. Escala AE Generalizada; 2. Escala de Desempenho Acadêmico } \\
\text { Geral e por Areas }\end{array}$ \\
\hline $\begin{array}{l}\text { Di Fabio \& Kenny } \\
\qquad(2015)\end{array}$ & $n=254 ;{ }^{\mathrm{a}},{ }^{\mathrm{c}}$ & $\begin{array}{l}\text { 1. Career Decision Self-efficacy Scale; } 2 \text {. Bar-On Emotional Quotient } \\
\text { Inventory, Teacher and Friend Perceived Social Support Scale, Self- } \\
\text { perceived Employability Scale for Students }\end{array}$ \\
\hline $\begin{array}{l}\text { Gaxiola \& Armenta } \\
\qquad(2016)\end{array}$ & $n=250 ;{ }^{\mathrm{a}}$ & $\begin{array}{l}\text { 1. Cuestionario sobre la AE Académica; 2. Modelo estrutural de } \\
\text { desempenho acadêmico }\end{array}$ \\
\hline $\begin{array}{l}\text { Gonzalez, Stein, } \\
\text { Kiang, \& Cupito } \\
\quad(2014)\end{array}$ & $n=179 ;{ }^{\text {a }}{ }^{\mathrm{c}}$ & $\begin{array}{l}\text { 1. College-Going Self-efficacy Scale; 2. Psychological Sense of } \\
\text { School Membership Scale, Moods and Feelings Questionnaire, Way } \\
\text { Discrimination Scale, Social Support Scale }\end{array}$ \\
\hline $\begin{array}{l}\text { Guerreiro-Casanova, } \\
\text { Dantas, \& Azzi (2011) }\end{array}$ & $n=534 ;{ }^{\mathrm{a}}{ }^{\mathrm{b}}$ & $\begin{array}{l}\text { 1. Escala de AE Acadêmica; 2. Inventário de Estratégias de Estudo } \\
\text { e Aprendizagem }\end{array}$ \\
\hline Gushue (2006) & $n=128 ;{ }^{\mathrm{a}}$ & $\begin{array}{l}\text { 1. Career Decision-making Self-efficacy Scale; 2. Ethnic Identity } \\
\text { Measure, Career Outcome Expectations }\end{array}$ \\
\hline Johnson et al. (2012) & $\begin{array}{l}n=473 \text { África, } \\
n=81 \text { EUA; }{ }^{\mathrm{d}}\end{array}$ & $\begin{array}{l}\text { 1. General Self-efficacy Scale; 2. Multigroup Ethnic Identity } \\
\text { Measure, Diversity Attitudes Scale of the Civic Attitudes and Skills } \\
\text { Questionnaire, Open-ended questions }\end{array}$ \\
\hline $\begin{array}{l}\text { Leal, Melo-Silva, \& } \\
\text { Teixeira (2015) }\end{array}$ & $n=241 ;{ }^{\mathrm{a}}, \mathrm{b}$ & $\begin{array}{l}\text { 1. Inventário de AE em Desenvolvimento da Carreira; 2. Classificação } \\
\text { Econômica Brasil }\end{array}$ \\
\hline Matias et al. (2009) & $n=316 ;{ }^{\text {a }}$ & $\begin{array}{l}\text { 1. Escala de AE Geral; 2. Questionário de Avaliação do Estilo de } \\
\text { Vida, Questionário de Atividades Físicas, Questionário de Mudança } \\
\text { de Comportamento para a Atividade Física }\end{array}$ \\
\hline $\begin{array}{l}\text { Noronha \& Ambiel } \\
\qquad(2008)\end{array}$ & $\begin{array}{c}n=35 \text { jovens, } \\
n=35 \text { genitores; }{ }^{\mathrm{a}}, \mathrm{b}\end{array}$ & $\begin{array}{l}\text { 1. Escala AE para Atividades Ocupacionais; 2. Escala } \\
\text { Aconselhamento Profissional }\end{array}$ \\
\hline $\begin{array}{l}\text { Nunes \& Noronha } \\
\quad(2009)\end{array}$ & $n=333 ;^{\text {a }}$ & $\begin{array}{l}\text { 1. Escala AE para Atividades Ocupacionais; } 2 . \text { Self-directed Search } \\
\text { Career Explorer }\end{array}$ \\
\hline $\begin{array}{l}\text { Nunes \& Noronha } \\
\quad(2011)\end{array}$ & $n=289 ;{ }^{\text {a }}$ & $\begin{array}{l}\text { 1. Escala AE para Atividades Ocupacionais; } 2 \text {. Self-directed Search } \\
\text { Career Explorer, Escala Aconselhamento Profissional }\end{array}$ \\
\hline $\begin{array}{l}\text { Sanmartín et al. } \\
\qquad(2011)\end{array}$ & $n=822 ;{ }^{\text {a }}$ & $\begin{array}{l}\text { 1. Multidimensional Scales of Self-efficacy; 2. Index of Empathy, } \\
\text { Prosocial Behaviour, Contextual Self-responsibility Questionnaire }\end{array}$ \\
\hline Souza et al. (2013) & $n=1698 ;^{\text {a }}$ & $\begin{array}{l}\text { 1. Escala AE para atividade física; 2. Questionário de frequência } \\
\text { semanal de atividade fisica }\end{array}$ \\
\hline $\begin{array}{l}\text { Ventura \& Noronha } \\
\qquad(2014)\end{array}$ & $n=142 ;{ }^{\mathrm{a}},{ }^{\mathrm{b}}$ & $\begin{array}{l}\text { 1. Escala AE na Escolha Profissional; 2. Inventário Suporte Familiar, } \\
\text { Escalas: Responsividade/Exigência }\end{array}$ \\
\hline $\begin{array}{l}\text { Yap \& Baharudin } \\
(2016)\end{array}$ & $n=802 ;{ }^{\text {a }}$ & $\begin{array}{l}\text { 1. Self-efficacy Questionnaire; 2. Paternal/Maternal Involvement } \\
\text { Scales, Negative Affect Schedule, Students' Life Satisfaction Scale }\end{array}$ \\
\hline
\end{tabular}

${ }^{\text {a }}$ School; ${ }^{\text {b family; }}{ }^{\mathrm{c}}$ peer group; ${ }^{\mathrm{d}}$ community. 
adults); respect for social and cultural norms; connection (positive links with people and institutions, reflected in participation in social protests) and constructive use of time (engaging in creative activities).

Regarding the social domain of investigation shown in Table 3, 53\% of the studies involved only the school domain $(n=10)$, as in the studies conducted by Chung and Elias (1996) and Yap and Baharudin (2016), for example. There were also four studies (Guerreiro-Casanova et al., 2011; Leal et al., 2015; Noronha \& Ambiel, 2008; Ventura \& Noronha, 2014) that jointly investigated the school and family domains, as well as three studies (Carvajal et al., 1999; Di Fabio \& Kenny, 2015; Gonzalez et al., 2014) that analyzed the school domain and the peer group simultaneously. Finally, two studies investigated the community domain only (Braun-Lewensohn, 2015; Johnson et al., 2012). Considering the multiplicity of situations (favorable or not) that can contribute to PYD, it is particularly pertinent to investigate the healthy aspects experienced by young people in different social domains. Therefore, studies involving more than one social domain are relevant, considering the integral health of adolescents, as well as their adaptation to adult life.

It should be emphasized that the schools participating in the studies that had the school domain as the target were, predominantly, of the public school system. Regarding data analysis, the majority of the studies $(n=18)$ used quantitative methods, employing descriptive statistical analysis, factorial analysis, analysis of variance, linear and multiple regression, and multivariate and structural models. However, as previously mentioned, one study (Johnson et al., 2012) used a mixed method, with analysis of quantitative and qualitative data through analysis of the thematic content and frequency. In this direction, Cerqueira-Silva, Dessen, and Costa (2011) highlighted the supremacy of the use of quantitative methods, suggesting the performance of more studies that reconcile the use of mixed methods, given the lack of works combining these methods, as well as the need for better understanding of the critical components responsible for PYD.
Implications of the Association between Self-efficacy and Positive Development Resources

The set of publications revealed some factors that, according to the studies, present significant relationships between self-efficacy and PYD. The results of these associations are difficult to compare due to the great variability of the instruments used by the researchers. This difficulty is mainly present in the case of the evaluation of PYD resources, since according to Benson et al. (2006) these resources can be grouped according to several developmental objectives intrinsic and extrinsic to the subject. There is a wide variety of skills that can be promoted according to Catalano et al. (2004), who highlight 15 objective aspects (e.g., selfefficacy, belief in the future, bond, social competence). Also Benson et al. (2006) indicate 40 resources (e.g., support, empowerment, commitment to learn, positive identity), and Lerner et al. (2009) recommend five resources (competence, confidence, connection, character, and compassion), which is reflected in the subscales of the different instruments. Likewise, in the case of the evaluation of self-efficacy, Bandura (1977) highlighted that self-efficacy is related to a given situation and, therefore, directs researchers to construct evaluation measures for specific moments or multiple skills.

However, when analyzing the results of the studies, regardless of the instrument used, an approximation between the social domains investigated and the themes pertinent to the reality of each domain (school, family, peer group and community) could be observed. In studies emphasizing academic skills, one of the PYD resources focused on the school context, it was found that self-efficacy was significantly associated with academic performance in general, and with areas, such as arts, sciences, languages, social and mathematics (Contreras et al., 2005; Gaxiola \& Armenta, 2016). There were also significant differences in the beliefs of the students regarding academic self-efficacy (in the dimensions involving self-efficacy to learn and act in school life) according to the educational level of the parents (Guerreiro-Casanova et al., 2011). 
The adolescents whose parents had completed higher education showed a greater perception of academic self-efficacy, being more motivated to succeed in school, considering the references of their social surroundings. Thus, according to Benson (2003), both intrinsic (commitment to learn) and extrinsic (social support) resources are desirable for PYD.

In addition, with regard to the studies focused on academic skills, it was verified in the study conducted by Chung and Elias (1996) that higher scores in academic self-efficacy, as well as participation in various after-school activities and positive life events (e.g., receiving a medal of honor, getting a salary increase) were predictors of patterns of fewer behavioral problems in young people. These findings corroborate the evidence found by Catalano et al. (2004), demonstrating that the increase in the skills assessed, in the case of programs focusing on PYD, may correspond to a decrease in risk behaviors in adolescence. Equally in the study conducted by Yap and Baharudin (2016), it was found that academic self-efficacy was positively correlated with parental involvement, positive affect and life satisfaction, while social self-efficacy correlated with parental involvement and positive affect.

In this direction, the right and access to school are, in principle, protective indicators for the juvenile population, demonstrating the mediating and catalyzing power of self-efficacy beliefs both for school success and for a positive perception of the context of life. Therefore, it is important to emphasize that self-efficacy beliefs function as good predictors of performance for individuals who possess the basic skills required to fulfill a particular task (Bandura, 1997, 2006). Thus, skills are understood as an acquired and changeable attribute, in which the individual can exercise control, through practice and their development. Despite this, there has been very little study, specifically in Brazil, of the beliefs of academic self-efficacy, especially with regard to young high school students.

In relation to occupational activities and professional interests investigated in the school context, there were correlations between self- efficacy and professional interests according to sex, with higher scores among boys of the realist and entrepreneurial types and among girls of the social type (Nunes \& Noronha, 2009). It is suggested that confidence in the ability to perform occupational tasks is linked to socialization practices differentiated by sex, that is, teachers and other people probably stimulate young people differently in these activities, and in this sense, it becomes necessary for professionals in the field of vocational guidance, for example, to reflect on these findings. Likewise, Nunes and Noronha (2011) obtained significant correlations between self-efficacy and types of artistic and social interests, with self-efficacy associated with the sex variable being a predictor of types of realistic and social interest and of the exact sciences. Regarding the professional interests investigated in the family and school contexts, according to Noronha and Ambiel (2008), there was a significant correlation between self-efficacy and the interest of the parents in exact sciences. These findings suggest a tendency for parents to transmit to children patterns of interest in exact sciences. In addition, in the study by Ventura and Noronha (2014), the affectivity of family members and maternal responsiveness (mother's posture of understanding) was a predictor of greater selfefficacy for professional choice. These findings are supported in the literature by Almeida e Melo-Silva (2011), Almeida and Pinho (2008) and Benson (2003), emphasizing that the greater the amount of family support, the greater the person's perception of his/her capacity to perform a task, highlighting the relevance of the development of extrinsic resources to increase self-efficacy.

According to Leal et al. (2015), in relation to another intrinsic resource of PYD, career skills, analyzed in relation to the school, family and the peer group domains, a significant association between self-efficacy (confidence in career planning, in preparation to find a job and effective search for a job) and socioeconomic status was found. The findings revealed that an environment with broader educational/cultural opportunities is desirable, as also emphasized 
by Damon (2004) referring to the resources of different social domains (school, family, peers) tending to maximize PYD. In the study by Gushue (2006), self-efficacy for career decisionmaking correlated positively with the ethnic identity of the young people, suggesting that the identification of students with their ethnic groups, or their cultural values, may emerge as an important aspect in career counseling and education. However, in the study by Di Fabio and Kenny (2015) no correlation was found between self-efficacy and emotional intelligence or between self-efficacy and social support. For the researchers, one possible justification was that self-efficacy may include specific skills in obtaining occupational information, career planning, and decision making that go beyond the emotional skills and social support normally offered by teachers and other adults.

With regard to physical skills in the school context, also an intrinsic resource derived from PYD, the results found in the study by Matias et al. (2009), which aimed to investigate the lifestyle, the habitual level of physical activity and the perception of self-efficacy of the young people, indicated that high self-efficacy predicted a better life style, and that sedentary boys presented greater self-efficacy than sedentary girls. However, the practice of physical activity was related to greater self-efficacy for the girls. The authors, while also observing that the active young people had a better lifestyle, suggested that this behavior, together with a greater perception of self-efficacy, is important in the formation of healthy life habits. Likewise, Souza et al. (2013) found a positive association between selfefficacy and physical activity, however, with more consistency among girls than among boys. In general, the researchers mentioned inferred that raising self-efficacy levels in adolescence may be an important component in strategies for promoting physical activity.

Considering the other studies found, they were not grouped by common themes, due to the diversity of overlapping themes. Thus, the results and the main discussions on these studies are displayed separately. In the study by Gonzalez et al. (2014), there was a significant correlation between self-efficacy to continue the studies or to follow a higher education course, the sense of connection with the school context and the social support of the peer group. These positive associations also suggest that peer support appears to have a protective effect, e.g., against discrimination, as the study involved Latino youths living in the USA. Confirming these findings, Bandura (1997) and Benson (2003) argued that the positive influence of peers (one of the extrinsic resources of PYD) is essential to actively reconstruct self-efficacy beliefs in adolescence.

In the study of Sanmartín et al. (2011), selfefficacy, pro-social behavior and empathy were predictors of the personal and social responsibility of the students, a feature that is highlighted in PYD as intrinsic to the subject (Benson, 2003). From a practical point of view, knowledge of the predictive psychological variables of PYD is an essential first step in the development of intervention programs aimed at promoting youth health (Benson et al., 2006; Lerner et al., 2009). Therefore, PYD has begun to influence interventions that, in addition to prevention, promote social, behavioral and cognitive development.

With regard to the work of Johnson et al. (2012), there was a significant correlation between self-efficacy and ethnic identity in the general sample (Africa and USA), and in the participants of Tanzania and Uganda, as well as between age and self-efficacy. The open questions demonstrated gains in intercultural relationships/ attitudes and self-efficacy, according to the reports of the adolescents. These findings reinforce the applicability of interrelated constructs of ethnic identity, self-efficacy and intercultural attitudes, in different contexts. Specifically, regarding self-efficacy, the benefits of promoting it among African participants were highlighted, given the precariousness of resources (school materials, extra-class activities) in this context compared to the American youths.

According to the results obtained by BraunLewensohn (2015), a greater sense of self-efficacy for citizenship was correlated with greater engagement of the young people, whereas the perception of different values (social and cul- 
tural) was a predictor of greater self-efficacy for citizenship, engagement of the young people and hope. From this, it is important to emphasize the importance of the constructive use of time (such as engaging in creative activities), also an extrinsic resource of PYD, capable of improving civic participation and citizen self-efficacy among adolescents, as emphasized by Benson (2003; Benson et al., 2006).

Finally, in the study conducted by Carvajal et al. (1999), the only one with a longitudinal design, self-efficacy was only moderately predictive of the postponement of the first sexual relationship in adolescence. The authors suggested that young people with positive attitudes who were committed to social norms and those whose parents had completed higher education were less likely to engage in sexual intercourse during the follow-up period (up to approximately 2 years). Therefore, the character - respect for social/cultural norms, morality and integrity - (Lerner et al., 2009) and the family influence (Benson, 2003) were found to be effective for postponing the first sexual intercourse. However, it is still necessary to evaluate these psychosocial resources in different samples, regarding gender, ethnicity and parental level of schooling, for example, so that the priority strategies to be adopted in the interventions can be indicated, aiming to reduce the risk behaviors related to infection, and other sexually transmitted diseases, as well as early pregnancy in adolescence.

Given the results reported here, there was a lack of national studies addressing the relationship between self-efficacy and positive and health promotion resources in adolescence. As indicated by Coimbra and Fontaine (2015), considering the challenges experienced by the current generation of adolescents, with longer periods of family education and schooling and an extended transition to adult life, it is evident that young people need more awareness to deal with the frustrations and limits imposed by the presence of other people with their own rights and desires. It is for health and education professionals, as promoters of mental health and development, to approach other social sectors to act on the psychosocial determinants inherent in the process of youth development. To this end, these professionals are increasingly required to prepare policies aimed at the young population, who have suffered from the lack of social policies that support proactive intervention proposals in this important developmental stage.

\section{Final Considerations}

With regard to the contributions of this study, its innovative character stands out as there is a lack of studies on the subject addressed, with a lack of discussion in the national context. It should be noted that this more positive perspective of development reflects the view that, on one hand, adolescents have intrinsic resources or strengths, while on the other, schools, families, peers and the community provide the resources that can promote the empowerment of young people, including the experiences and opportunities that contexts can provide for better performance in fulfilling developmental tasks. From this perspective, self-efficacy beliefs are considered to be a key variable when it comes to promoting and improving performance in different areas, as they have a direct relationship with learning processes.

The present review presented studies with samples composed mainly of adolescents, however, expanding this theme with samples of populations in other stages of development would be extremely relevant. Therefore, it is recommended to cover the entire spectrum of the life course, preferably by means of longitudinal studies, and not to concentrate the research only on one social dimension, as has been confirmed in relation to the selected studies, which exclusively focused either on the school or on the community domain. It should also be noted that the studies reviewed used different instruments to evaluate the PYD resources and the self-efficacy beliefs, with the theoretical models possibly presenting some differences.

In addition, this review also presents limitations, since there are other descriptors that can be used to find more studies on the topic addressed. Therefore, the studies identified 
here may differ from the number of studies that exist, as publications focusing on the relationship between PYD and self-efficacy were not widely retrieved. Another limiting factor is the difficulty of comparing the results of the studies found, considering the diversity of instruments and/or resources detected, which does not allow for generalizations. However, the present study indicates that studies investigating the relationship between PYD resources and self-efficacy beliefs in a more dialogic way can contribute to planning, as well as provide support for proactive programs with young people. Another factor that contributes to the limitation of the data presented here is that the various studies that have been performed were carried out in different countries, or different sociocultural contexts, which need to be reinterpreted within the Brazilian context.

Nevertheless, as verified in the academic production studied, this narrative review demonstrated how self-efficacy beliefs are associated with some of the positive developmental resources in adolescence. The results showed that the association between self-efficacy and PYD resources (e.g., academic, physical and career skills; social support; respect for social and cultural norms; connection with people and institutions; and positive values such as responsibilities, etc.) has been the subject of a limited number of studies. This seems to be due to the short time of inclusion in the scientific literature of the concepts of self-efficacy associated with healthy resources, since among the publications found the first corresponded to the year 1996. Therefore, new investigations related to the subject matter reported here are of relevance to extend the discussion and fill existing gaps regarding increasing positive qualities and protective factors in adolescence in order to foster positive interventions and to transform youths into more proactive people to confront adversity, make healthy choices, and determine courses of action for their lives.

It is concluded that the relationship between self-efficacy and the varied resources of positive youth development is a promising research problem, as it favors the perspective of prevention and health promotion in adolescence. As indicated, young people, when constantly confronted with stressful situations, need greater cognitive flexibility, so that, considering the reality in which they live, they achieve a more satisfactory adaptation when confronting adverse situations, in order to overcome these situations with new skills.

\section{References}

Almeida, F. H., \& Melo-Silva, L. L. (2011). Influência dos pais no processo de escolha profissional dos filhos: Uma revisão da literatura. PsicoUSF, 16(1), 75-85. Retrieved from http://producao.usp.br/handle/BDPI/6729

Almeida, M. E. G. G., \& Pinho, L. V. (2008). Adolescência, família e escolhas: Implicações na orientação profissional. Psicologia Clínica, 20(2), 173-184. Retrieved from http://www. scielo.br/pdf/pc/v20n2/a13v20n2

Azzi, R. G., \& Polydoro, S. A. J. (Eds.). (2006). Autoeficácia em diferentes contextos. Campinas, SP: Alínea.

Bandura, A. (1977). Self-efficacy: Toward a unifying theory of behavioral change. Psychological Review, 84, 191-215. doi: http://dx.doi. org/10.1037/0033-295X.84.2.191

Bandura, A. (1997). Self-efficacy: The exercise of control. New York: W. H. Freeman and Company.

Bandura, A. (2004). Health promotion by social cognitive means. Health Education \& Behavior, 31(2), 143-164.

Bandura, A. (2006). Guide for constructing self-efficacy scales. In F. Pajares \& T. C. Urdan (Eds.), Adolescence and education (Vol. 5, pp. 307337). Greenwich, CT: Information Age.

Bandura, A. (2008). A evolução da teoria social cognitiva. In A. Bandura, R. G. Azzi, \& S. A. J. Polydoro (Eds.), Teoria social cognitiva: Conceitos básicos (pp. 15-41). Porto Alegre, RS: Artmed.

Benetti, S. P. C., Ramires, V. R. R., Schneider, A. C., Rodrigues, A. P. G., \& Tremarin, D. (2007). Adolescência e saúde mental: Revisão de artigos brasileiros publicados em periódicos nacionais. Cadernos de Saúde Pública, 23(6), 1273-1282. doi: 10.1590/S0102-311X2007000600003 
Benson, P. L. (2003). Developmental assets and asset building communities: Conceptual and empirical foundations. In R. M. Lerner \& P. L. Benson (Eds.), Developmental assets and asset-building communities: Implications for research, policy, and practice (pp. 19-43). Norwell, MA: Kluwer Academic.

Benson, P. L., \& Scales, P. C. (2009). The definition and preliminary measurement of thriving in adolescence. Journal of Positive Psychology, 4, 85-104. doi: http://dx.doi. org/10.1080/17439760802399240

Benson, P. L., Scales, P. C., Hamilton, S. F., Sesma, A., Jr., Hong, K. L., \& Roehlkepartain, E. C. (2006). Positive youth development so far: Core hypotheses and their implications for policy and practice. Search Institute Insights \& Evidence, $3(1), 1-13$

*Braun-Lewensohn, O. (2015). Sense of coherence, values, youth involvement, civic efficacy and hope: Adolescents during social protest. Social Indicators Research. doi: 10.1007/s11205-0151049-8

*Carvajal, S. C., Parcel, G. S., Banspach, S. W., Basen-Engquist, K., Coyle, K. K., Kirby, D., \& Chan, W. (1999). Psychosocial predictors of delay of first sexual intercourse by adolescents. Health Psychology, 18(5), 443-452. doi: http:// dx.doi.org/10.1037/0278-6133.18.5.443

Catalano, R. F., Berglund, M. L., Ryan, J. A. M., Lonczak, H. S., \& Hawkins, J. D. (2004). Positive youth development in the United States: Research findings on evaluations of positive youth development programs. The Annals of the American Academy of Political and Social Science, 591(1), 98-124. doi: $10.1177 / 0002716203260102$

Cerqueira-Silva, S., Dessen, M. A., \& Costa, A. L. C., Jr. (2011). As contribuições da ciência do desenvolvimento para a psicologia da saúde. Ciência \& Saúde Coletiva, 16(1), 1599-1609. doi: http:// dx.doi.org/10.1590/S1413-81232011000700096

*Chung, H., \& Elias, M. (1996). Patterns of adolescent involvement in problem behaviors: Relationship to self-efficacy, social competence, and life events. American Journal of Community Psychology, 24(6). doi: 10.1007/BF02511034

Coimbra, S., \& Fontaine, A. M. V. G. (2015). Resiliência e habilidades sociais: Reflexões conceituais e práticas para uma nova geração. In
Z. A. P. Del Prette, A. B. Soares, C. S. PereiraGuizzo, M. F. Wagner, \& V. B. R. Leme (Eds.), Habilidades sociais: Diálogos e intercâmbios sobre pesquisa e prática (pp. 186-220). Novo Hamburgo, RS: Sinopsys.

Connor, J. P., George, S. M., Gullo, M. J., Kelly, A. B., \& Young, R. M. (2011). A prospective study of alcohol expectancies and self-efficacy as predictors of young adolescent alcohol misuse. Alcohol and Alcoholism, 46, (2), 161-169. doi: http://dx.doi.org/10.1093/alcalc/agr004

*Contreras, F., Espinosa, J. C., Esguerra, G., Haikal, A., Polanía, A., \& Rodríguez, A. (2005). Autoeficacia, ansiedad y rendimento académico en adolescentes. Perspectivas en Psicología, 1(2), 183-194. Retrieved from http://www. redalyc.org/articulo.oa?id $=67910207$

Damon, W. (2004). What is positive youth development? The Annals of the American Academy of Political and Social Science, 591(1), 13-24.

*Di Fabio, A., \& Kenny, M. E. (2015). The contributions of emotional intelligence and social support for adaptive career progress among Italian youth. Journal of Career Development, 42(1), 48-59. doi: 10.1177/0894845314533420

Erikson, E. (1976). Identidade, juventude e crise (2nd Ed.). Rio de Janeiro, RJ: Zahar (Original work published in 1968)

Franco, G. R., \& Rodrigues, M. C. (2014). Programas de intervenção na adolescência: Considerações sobre o desenvolvimento positivo do jovem. Temas em Psicologia, 22(4), 677-690. doi: 10.9788/TP2014.4-01

*Gaxiola, M. I. B., \& Armenta, M. F. (2016). Factores que influyen en el desarrollo y rendimiento escolar de los jóvenes de Bachillerato. Revista Colombiana de Psicología, 25(1), 63-82. doi: 10.15446/rcp.v25n1.46921

*Gonzalez, L. M., Stein, G. L., Kiang, L., \& Cupito, A. M. (2014). The impact of discrimination and support on developmental competencies in Latino adolescents. Journal of Latina/o Psychology, 2(2), 79-91. doi: 10.1037/lat0000014

Grant, M. J., \& Booth, A. (2009). A typology of reviews: An analysis of 14 review types and associated methodologies. Health Information and Libraries Journal, 26(2), 91-108. doi: 10.1111/j.1471-1842.2009.00848.x

*Guerreiro-Casanova, D. C., Dantas, M. A., \& 
Azzi, R. G. (2011). Autoeficácia de alunos do ensino médio e nível de escolaridade dos pais. Estudos Interdisciplinares em Psicologia, 2(1), 36-55. doi: http://dx.doi.org/10.5433/22366407.2011v2n1p36

*Gushue, G. V. (2006). The relationship of ethnic identity, career decision-making self-efficacy and outcome expectations among Latino/a high school students. Journal of Vocational Behavior, 68, 85-95. doi: 10.1016/j.jvb.2005.03.002

Hyde, J., Hankins, M., Deale, A., \& Marteau, T. M. (2008). Interventions to increase selfefficacy in the context of addiction behaviours: A systematic literature review. Journal of Health Psychology, 13, (5), 607-623. doi: $10.1177 / 1359105308090933$

*Johnson, L. R., Ha Kim, E., Johnson-Pynn, J. S., Schulenberg, S. E., Balagaye, H., \& Lugumya, D. (2012). Ethnic identity, self-efficacy, and intercultural attitudes in East African and U.S. youth. Journal of Adolescent Research, 27(2), 256-289. doi: 10.1177/0743558411412955

*Leal, M. S., Melo-Silva, L. L., \& Teixeira, M. O. (2015). Crenças para lidar com tarefas de carreira em estudantes do ensino médio. Avaliação Psicológica, 14(1), 125-132. doi: 10.15689/ ap.2015.1401.14

Lerner, R. M., \& Galambos, N. L. (1998). Adolescent development: Challenges and opportunities for research, programs, and policies. Annual Review of Psychology, 49, 413-446.

Lerner, J. V., Phelps, E., Forman, Y., \& Bowers, E. P. (2009). Positive youth development. In R. M. Lerner \& L. Steinberg (Eds.), Handbook of adolescent psychology ( $3^{\text {rd }}$ Ed., pp. 524-558). Hoboken, NJ: Wiley.

*Matias, T. S., Rolim, M. K. S. B., Kretzer, F. L., Schmoelz, C. P., Vasconcellos, D. I. C., \& Andrade, A. (2009). Estilo de vida, nível habitual de atividade física e percepção de autoeficácia de adolescentes. Revista da Educação Físical UEM, 20(2), 235-243. doi: 10.4025/reveducfis. v20i2.6413

Ministério da Saúde. Secretaria de Vigilância em Saúde. Secretaria de Atenção à Saúde. (2010). Política Nacional de Promoção da Saúde (3 ${ }^{\text {rd }}$ Ed.). Brasília, DF: Ministério da Saúde.

*Noronha, A. P. P., \& Ambiel, R. A. M. (2008). Fontes de eficácia e interesses profissionais: Relações entre pais e filhos. Evaluar, 8, 32-45.
Retrieved from https://revistas.unc.edu.ar/index. php/revaluar/article/view/503/459

*Nunes, M. F. O., \& Noronha, A. P. P. (2009). Autoeficácia para atividades ocupacionais e interesses profissionais em estudantes do ensino médio. Psicologia, Ciência e Profissão, 29(1), 102-115. Retrieved from http://www.scielo.br/pdf/pcp/ v29n1/v29n1a09

*Nunes, M. F. O., \& Noronha, A. P. P. (2011). Associações entre auto-eficácia para atividades ocupacionais e interesses em adolescentes. Psicologia: Reflexão e Crítica, 24(1), 1-9. Retrieved from http://www.scielo.br/pdf/prc/ v24n1/v24n1a02

Pacico, J. C., Ferraz, S. B., \& Hutz, C. S. (2014). Autoeficácia - Yes we can! In C. S. Hutz (Ed.), Avaliação em psicologia positiva (pp. 111-119). Porto Alegre, RS: Artmed.

Pan American Health Organization. (2007). Health agenda for the Americas 2008-2017. Panama City, Panama: Author. Retrieved from http:// www.paho.org/English/DD/PIN/Health_Agenda.pdf

Rother, E. T. (2007). Revisão sistemática x revisão narrativa [Editorial]. Acta Paulista de Enfermagem, 20(2), v-vi. doi: http://dx.doi.org/10.1590/ S0103-21002007000200001

*Sanmartín, M. G., Carbonell, A. E., \& Baños, C. P. (2011). Relaciones entre empatía, conducta prosocial, agresividad, autoeficacia y responsabilidad personal y social de los escolares. Psicothema, 23(1), 13-19. Retrieved from http://www.psicothema.com/PDF/3843.pdf

Santrock, J. W. (2014). Adolescência (14 ${ }^{\text {th }}$ Ed.). Porto Alegre, RS: AMGH.

Sbicigo, J. B., Teixeira, M. A. P., Dias, A. C. G., \& Dell'Aglio, D. D. (2012). Propriedades psicométricas da escala de autoeficácia geral percebida (EAGP). Psico, 43(2), 139-146. Retrieved from https://dialnet.unirioja.es/ servlet/articulo? codigo $=5163218$

Seligman, M. E. P. (2011). Florescer: Uma nova compreensão sobre a natureza da felicidade $e$ do bem-estar. Rio de Janeiro, RJ: Objetiva.

Senna, S. R. C. M., \& Dessen, M. A. (2012). Contribuições das teorias do desenvolvimento humano para a concepção contemporânea da adolescência. Psicologia: Teoria e Pesquisa, 28(1), 101108. Retrieved from http://www.scielo.br/pdf/ $\mathrm{ptp} / \mathrm{v} 28 \mathrm{n} 1 / 13$ 
*Souza, C. A., Rech, C. R., Sarabia, T. T., Añez, C. R. R., \& Reis, R. S. (2013). Autoeficácia e atividade física em adolescentes de Curitiba, Paraná, Brasil. Cadernos de Saúde Pública, 29(10), 2039-2048. doi: http://dx.doi.org/10.1590/0102$311 \mathrm{X} 00127312$

*Ventura, C. D., \& Noronha, A. P. P. (2014). Autoeficácia para escolha profissional, suporte familiar e estilos parentais em adolescentes. Avaliação Psicológica, 13(3), 317-324. Retrieved from https://dialnet.unirioja.es/servlet/ articulo?codigo $=5115078$

Veselska, Z., Geckova, A. M., Reijneveld, S. A., \& Dijk, J. P. (2011). Self-efficacy, affectivity and smoking behavior in adolescence. European Addiction Research, 17, (4), 172-177. doi: $10.1159 / 000326071$

World Health Organization. (1986, November 21). Ottawa, Canada. In Ottawa Charter for Health Promotion. First International Conference on
Health Promotion. Ottawa, Canada: Canadian Public Health Association. Retrieved from http:/www.who.int/healthpromotion/conferences/previous/ottawa/en/

World Health Organization. (2013). World health report: Research for universal health coverage. Retrieved from http://www.who.int/whr/en/

*Yap, S. T., \& Baharudin, R. (2016). The relationship between adolescents' perceived parental involvement, self-efficacy beliefs, and subjective well-being: A multiple mediator model. Social Indicators Research, 126, 257-278. doi 10.1007/ s11205-015-0882-0 